a graft-assisted anastomosis between the ascending aorta and the supraceliac abdominal aorta. ${ }^{2}$ In our patient, a graft was implanted between the ascending and descending aortas.

To avoid uncontrolled bleeding, there are 3 aspects that must be focused on perioperatively. First, all ductal tissue must be aggressively removed. Otherwise the anastomosis between the graft and the aorta will be susceptible to bleeding. Second, the anastomosis should be free of tension. Careful study of CT scans and better preoperative preparation are helpful to achieve complete dissociation of the descending aorta. More important, implanting a conduit will assist in reducing the tension. Third, pressuring hemostasis is effective when uncontrolled bleeding occurs. A bandage was placed with a little pressure on the stoma and thoracic cavity. One of the tips was placed out of the thoracic cavity. The bleeding volume was $900 \mathrm{~mL}$ on postoperative day 1 and $350 \mathrm{~mL}$ on postoperative day 2 . The hemostasis technique was an effective way to manage uncontrolled bleeding in this patient.

Because of the pulmonary artery aneurysm and the difficulty in exposing the PDA and descending aorta in this patient, we used the left femoral artery to perfuse the lower body. With these methods, circulatory arrest of the lower body was avoided and the risk of neurologic complications was minimized. The postoperative course was uneventful. The patient was discharged and has fully recovered.

\section{References}

1. Brown JW, Rezmetov M, Okada Y, Vijay P, Rodefeld MD, Turrentine MW. Outcomes in patients with interrupted aortic arch and associated anomalies: a 20-year experience. Eur J Cardiothorac Surg. 2006;29:666-74.

2. Krishna CS, Bhan A, Sharma S, Kiran U, Venugopal P. Interruption of aortic arch in adults: surgical experience with extra-anatomic bypass. Tex Heart Inst J. 2005; $32: 147-50$.

\title{
A new concept for correction of systolic anterior motion and mitral valve regurgitation in patients with hypertrophic obstructive cardiomyopathy
}

\author{
Joerg Seeburger, MD, Jurgen Passage, MBBS, Michael A. Borger, MD, PhD, and \\ Friedrich Wilhelm Mohr, MD, PhD, Leipzig, Germany
}

In patients with hypertrophic obstructive cardiomyopathy (HOCM), systolic anterior motion (SAM) of the anterior mitral leaflet (AML) can occur as a result of acceleration of flow in the left ventricular outflow tract. In addition, relative shortening of the chordae tendineae may reduce AML mobility and contribute to the generation of mitral regurgitation (MR). We present a new concept for correction of SAM and MR in patients with HOCM and restricted AML movement.

\footnotetext{
From the Department of Cardiac Surgery, Heartcenter, Leipzig University, Leipzig, Germany.

Received for publication Dec 11, 2009; accepted for publication Jan 1, 2010; available ahead of print March 26, 2010.

Address for reprints: Joerg Seeburger, MD, Heartcenter, Leipzig University, Struempelstrasse 39, 04289 Leipzig (E-mail: seej@med.uni-leipzig.de).

J Thorac Cardiovasc Surg 2010;140:481-3

$0022-5223 / \$ 36.00$

Copyright $(c) 2010$ by The American Association for Thoracic Surgery

doi:10.1016/j.jtcvs.2010.01.010
}

\section{METHODS}

The procedure consists of 2 stages, septal myectomy followed by complete resection and replacement of all AML chordae with the loop technique $^{1,2}$ (Figure 1). Myectomy enlarges the left ventricular outflow tract and reduces the risk of SAM. Resection of the foreshortened chordae to the AML and replacement with longer neochordae also reduces the risk of residual postoperative SAM and subsequent MR.

\section{RESULTS}

Since March 2008, 4 consecutive patients with HOCM, severe SAM, and evidence of restricted AML movement have been operated according to this new concept. In all cases, loops (average 8 per patient; range, 7-9) measuring $26 \mathrm{~mm}$ in length were implanted from both papillary muscles to the free margin of the AML. A flexible posterior band was implanted in 3 patients. Perioperative course was uneventful, with no major adverse events in all cases. Predischarge control showed no evidence of SAM and/or MR. 


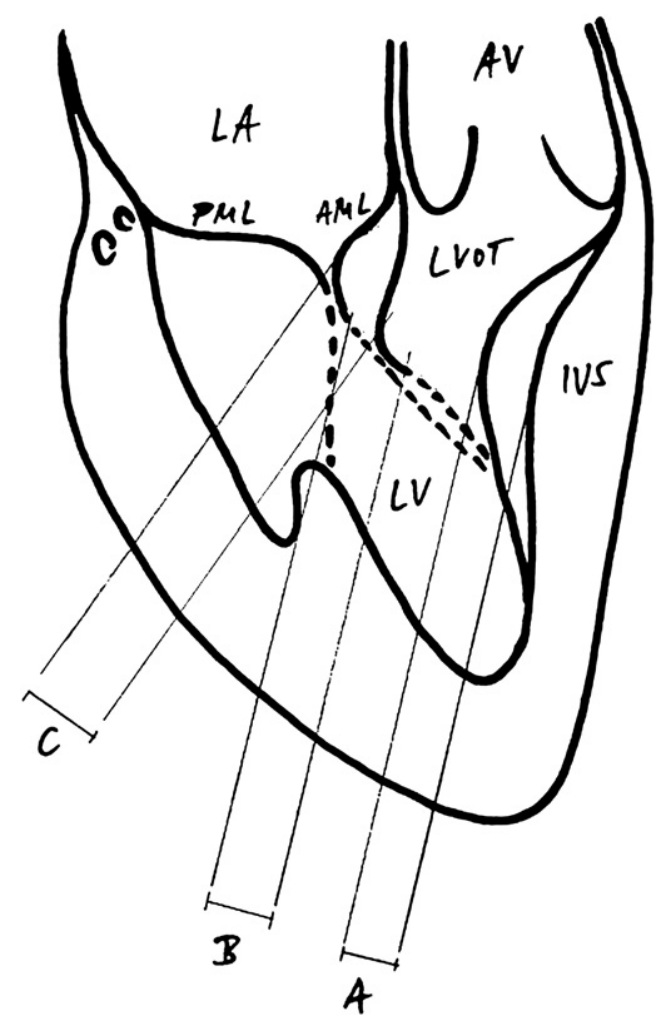

FIGURE 1. Benefits of myectomy in widening left ventricular outflow tract (LVOT) diameter (A), of longer neochordae for further extension of left ventricular outflow tract diameter $(B)$, and of neochordae for correction of mitral regurgitation by relocating anterior mitral leaflet $(A M L)$ toward annular plane $(C) . A V$, Aortic valve; $L A$, left atrium; $P M L$, posterior mitral leaflet; $I V S$, interventricular septum; $L V$, left ventricle.

\section{CONCLUSIONS}

Septal myectomy represents the surgical standard of care for HOCM. ${ }^{1}$ For cases of concomitant SAM, several other techniques have been described.

Chordae replacement has been pursued by Rankin and colleagues, ${ }^{3}$ with 1 patient undergoing complete resection of the anteromedial papillary muscle and subsequent implantation of neochordae to the posterolateral papillary muscle. Although this technique was successful, it would probably distract the subvalvular apparatus and AML as a result of diagonal forces toward the posterolateral muscle. AML extension with an oval pericardial patch in combination with myectomy has been described by Kofflard and associates. ${ }^{4}$ They presented long-term results of 20 patients, with sustained improvement in functional status and attenuation of MR and SAM. Schoendube and colleagues ${ }^{5}$ described an even more aggressive procedure consisting of reconstruction of the subvalvular apparatus by mobilization and partial excision of papillary muscles. They reported excellent functional improvement with relief of left ventricular outflow tract obstruction in 58 patients.

These techniques are all alike with regard to the use of myectomy but differ with regard to the leaflet procedures. As our initial experience shows, resection of foreshortened AML chordae with implantation of longer neochordae (loop technique) is highly effective (Figure 2). This new concept may represent an important treatment option for patients with the combination of HOCM, SAM, and restricted AML movement.

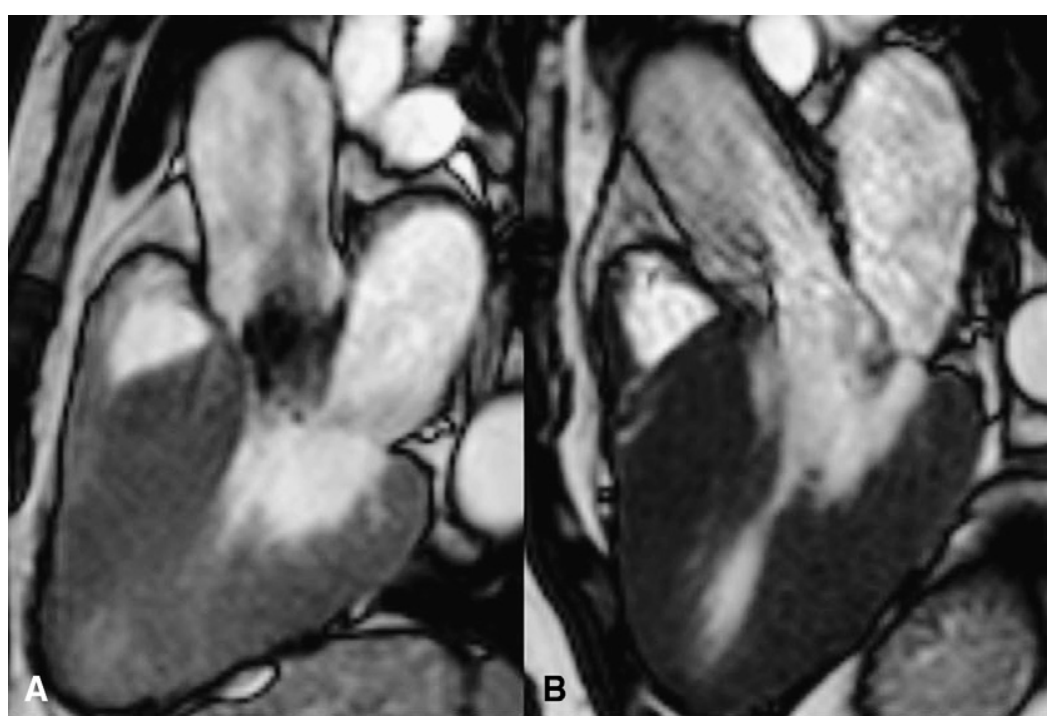

FIGURE 2. A, Preoperative magnetic resonance image with hypertrophy and severe systolic anterior motion. B, Postoperative magnetic resonance image reveals significantly enlarged left ventricular outflow tract with no systolic anterior motion. 


\section{References}

1. Morrow AG, Reitz BA, Epstein SE, Henry WL, Conkle DM, Itscoitz SB, et al. Operative treatment in hypertrophic subaortic stenosis. Techniques, and the results of pre and postoperative assessments in 83 patients. Circulation. 1975;52:88-102.

2. Seeburger J, Borger MA, Falk V, Mohr FW. Gore-Tex loop implantation for mitral valve prolapse: the Leipzig loop technique. Op Tech Thorac Cardiovasc Surg. 2008;13:83-90.

3. Rankin JS, Binford RS, Johnston TS, Matthews JT, Alfery DD, McRae AT, et al. A new mitral valve repair strategy for hypertrophic obstructive cardiomyopathy. J Heart Valve Dis. 2008;17:642-7.
4. Kofflard MJ, van Herwerden LA, Waldstein DJ, Ruygrok P, Boersma E Taams MA, et al. Initial results of combined anterior mitral leaflet extension and myectomy in patients with obstructive hypertrophic cardiomyopathy. J Am Coll Cardiol. 1996;28:203-6.

5. Schoendube FA, Klues HG, Reith S, Flachskampf FA, Hanrath P, Messmer BJ Long-term clinical and echocardiographic follow-up after surgical correction of hypertrophic obstructive cardiomyopathy with extended myectomy and reconstruction of the subvalvular mitral apparatus. Circulation. 1995;92(9 Suppl): II122-7.

\title{
Surgical repair of aortopulmonary window associated with interrupted aortic arch: Long-term outcomes
}

\author{
Igor E. Konstantinov, $\mathrm{MD}, \mathrm{PhD}$, Norihiko Oka, $\mathrm{MD}, \mathrm{PhD}$, Yves d'Udekem, $\mathrm{MD}, \mathrm{PhD}$, and
}

Christian P. Brizard, MD, Melbourne, Australia

Association of aortopulmonary window (APW) with interrupted aortic arch (IAA) is very rare. Only $3.5 \%$ to $4.2 \%$ of patients with IAA have APW. ${ }^{1-3}$ Thus the cumulative experience with this combination of lesions is limited to isolated case reports. The largest multi-institutional study of 20 patients operated on from 1987 to 1997 demonstrated survival of $91 \%, 86 \%$, and $84 \%$ at 1,5 , and 10 years, respectively. ${ }^{2}$ Furthermore, competing risk analysis estimated that at 5 years

From the Department of Cardiac Surgery, Royal Children's Hospital, the Department of Paediatrics, University of Melbourne, and Murdoch Children's Research Institute, Melbourne, Australia.

Disclosures: None.

Received for publication Oct 5, 2009; revisions received Nov 13, 2009; accepted for publication Dec 28, 2009; available ahead of print April 5, 2010.

Address for reprints: Igor E. Konstantinov, MD, PhD, Royal Children's Hospital, Flemington Rd, Parkville, Victoria 6009, Australia (E-mail: igor.konstantinov@ rch.org.au).

J Thorac Cardiovasc Surg 2010;140:483-4

0022-5223/\$36.00

Crown Copyright (c) 2010 Published by Elsevier Inc. on behalf of The American Association for Thoracic Surgery

doi:10.1016/j.jtcvs.2009.12.043 after repair, 51\% had arch reintervention, $6 \%$ had pulmonary artery reintervention, and only $43 \%$ were alive without reintervention. ${ }^{2}$ Herein we report the long-term outcomes of 5 patients from a single institution and describe our aortic mobilization and advancement technique, which resulted in a low reintervention rate in this rare subgroup of patients.

\section{CLINICAL SUMMARY}

Cardiopulmonary bypass is established through a median sternotomy. Patients were cooled to a mean of $19^{\circ} \mathrm{C}$. Mean cardiopulmonary bypass time was 69 minutes. Mean circulatory arrest time was 27 minutes. Mean aortic cross-clamp time was 40 minutes. The aortic arch, APW, and descending aorta were dissected (Figure 1, $A$ ). The descending aorta was extensively mobilized, and all ductal tissues were removed during circulatory arrest with cerebral perfusion (Figure 1, $B)$. The thick-walled ductal tissues were resected until the normal thin wall of the aorta appeared. The extent of the mobilization of the descending aorta was evolved to our currently used technique, in which at least 3 pairs of intercostal arteries are divided to ensure proper mobilization of the
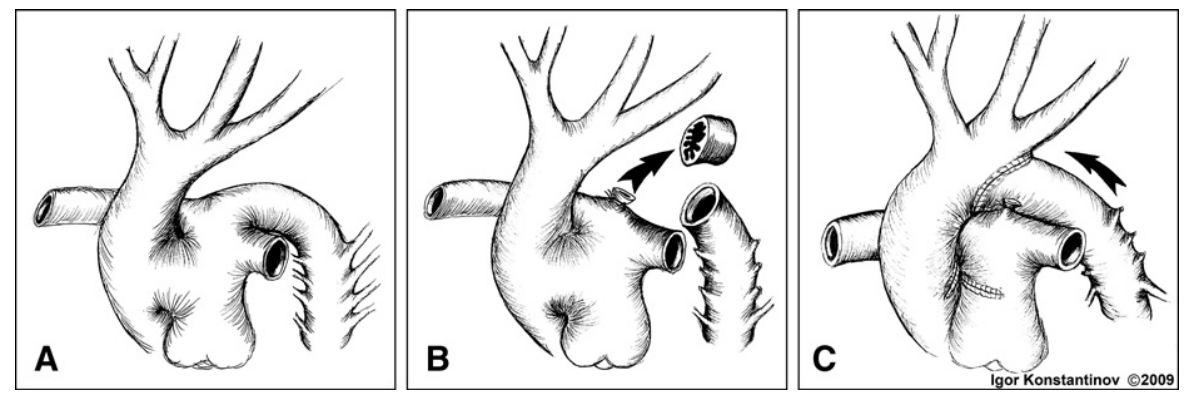

FIGURE 1. Aortic mobilization and advancement. A, Aortopulmonary window with interrupted aortic arch, type A. B, All ductal tissue is removed, and 3 pairs of intercostal arteries are divided to ensure adequate mobilization of the descending aorta. C, The descending aorta is anastomosed into the arch in an endto-side fashion. The aortopulmonary window is transected, and the resulting defects are closed individually with direct sutures. 